\title{
MAKING THE MOST OF COLLEGE
}

This book has been awarded Harvard University Press's annual prize for an outstanding publication about education and society, established in 1995 by the Virginia and Warren Stone Fund. 

RICHARD J. LIGHT

\section{MAKING THE \\ MOST OF COLLEGE}

\section{STUDENTS}

SPEAK

THEIR

MINDS

HARVARD

UNIVERSITY

PRESS

Cambridge,

Massachusetts

London,

England / 2001 
Copyright (C) 2001 by Richard J. Light

All rights reserved

Printed in the United States of America

Library of Congress Cataloging-in-Publication Data

Light, Richard J.

Making the most of college: students speak their minds/Richard J.

Light.

p. cm.

Includes bibliographical references (p. ) and index.

ISBN 0-674-00478-7 (cloth)

ISBN 0-674-01359-X (paper)

1. Harvard University-Students-Attitudes-Longitudinal studies.

2. College seniors-Attitudes-Longitudinal studies. I. Title.

LD2160.L54 2001

$378.1^{\prime} 98-\mathrm{dc} 21 \quad 00-059728$

Seventh printing, 2001 
I dedicate this book to my family. To Pat, who shares my life. To Jen and Sarah, who know they are the whole point of the enterprise. To my mother, Mura Light Stifel, who has given me a lifetime of love, and even suggested a title for this book. To Max, a kind, fun-loving stepfather. And most of all, to the memory of my father. 
